\title{
ИСТОРИЯ
}

УДК $94(930)$

\author{
ХОРЕЗМИЙСКОЕ И МОНГОЛЬСКОЕ ЗАВОЕВАНИЕ ЮЖНОГО КАВКАЗА \\ В ЗАРУБЕЖНОЙ ИСТОРИОГРАФИИ: НА ПРИМЕРЕ ИССЛЕДОВАНИЯ \\ Д. БАЙАРСАЙХАН «МОНГОЛЫ И АРМЯНЕ (1220-1335)» \\ (Работа выполнена при поддержке гранта РГНФ № 16-01-50028)
}

Тимохин Д.М.

ФГБУН Институт Востоковедения РАН, Москва

horezm83@mail.ru

\begin{abstract}
Аннотация: Статья посвящена анализу зарубежного исследовательского опыта в отношении монгольского и хорезмийского завоевания Южного Кавказа. В качестве объекта исследования была выбрана одна из наиболее современных работ по данной тематике - монография Д. Байарсайхан «Монголы и Армяне (1220-1335)». В статье подробно разбирается историографическая и источниковедческая часть представленной работы, а также те ее разделы, где автор непосредственно останавливается на описании монгольского и хорезмийского вторжения в земли Южного Кавказа, а также последствий этих завоевательных войн. Имеет значение для данного исследования и та часть монографии Д. Байарсайхан, где описывается политическое устройство Южного Кавказа в начале XIII в., а также целый ряд более ранних сюжетов. В этой статье анализируется и позиция Д. Байарсайхан по целому ряду дискуссионных моментов политической истории Южного Кавказа первой половины XIII в. Внимание автора статьи было привлечено и к тому, какое представление о политической истории Южного Кавказа первой половины XIII в. может сложиться у читателя после знакомства с исследованием Д. Байарсайхан «Монголы и Армяне (1220-1335)». Отдельную значимость данной статье придает тот факт, что монография Д. Байарсайхан до сих пор не переведена на русский язык и отечественным специалистам малоизвестна. Российская наука на данный момент не может похвастаться большим количеством современных специальных исследований по данной проблематике, поэтому крайне важно изучить зарубежный опыт в этой области.
\end{abstract}

Ключевые слова: монголы, армяне, историография, источниковедение, хорезмшах Джалал адДин Манкбурны, Грузия, Армения, Азербайджан, Ширван, Арран.

\section{KHWAREZMIAN AND MONGOL CONQUESTS OF THE SOUTH CAUCASUS IN FOREIGN HISTORIOGRAPHY: IN THE CONTEXT OF D. BAYARSAIKHAN'S RESEARCH «THE MONGOLS AND THE ARMENIANS (1220-1335)»}

(This work was supported by grant No. 16-01-50028 of the Russian Foundation for Human Rights)

Timokhin D.M.,

Federal State Funded Institution of Science 'Institute of Oriental Studies', Russian Academy of Sciences, Moscow

horezm83@mail.ru

Abstract: The article deals with the analysis of foreign researches of Mongol and Khwarezmian conquests of the South Caucasus. The subject of study is one of the latest works on this problem - D. 
Bayarsaikhan's monograph «The Mongols and the Armenians (1220-1335)». The author of the article details historiography and source study of the book under consideration, as well as those sections, which present the description of Mongol and Khwarezmian invasion of the territory of the South Caucasus and the consequences of these conquests. Much attention is given to the section of D.Bayarsaikhan's monograph describing the political structure of the South Caucasus at the beginning of the $13^{\text {th }}$ century and a number of earlier events. The author of the article also analyzes D. Bayarsaikhan's position on a number of debatable problems concerning political history of the South Caucasus in the first half of the $13^{\text {th }}$ century. The author focuses on the idea of political history of the South Caucasus in the first half of the $13^{\text {th }}$ century that readers may get after their acquaintance with D. Bayarsaikhan's book «The Mongols and the Armenians (1220-1335)». The fact that the monograph of D. Bayarsaikhan has not been translated into Russian yet and is not well known to specialists in Russia gives special significance to this article. To date, there are not many special studies on this problem in Russian science, therefore it is extremely important to study foreign experience in this field.

Keywords: Mongols, Armenians, historiography, source study, Khorezmshah Jalal ad-Din Mankburni, Georgia, Armenia, Azerbaijan, Shirvan, Arran.

В первой половине XIII в. Южный Кавказ становится объектом экспансии со стороны хорезмийской державы Джалал ад-Дина Манкбурны, а также монгольских завоевателей. Если последнему хорезмшаху не удалось надолго удержать этот регион под своей властью и полностью завоевать все его земли, то монголы сумели включить Южный Кавказ в состав Монгольской империи. Несмотря на значимость данного события для истории Южного Кавказа и сопредельных регионов, отечественная и зарубежная историография не располагает достаточным количеством специальных исследований по данной научной проблематике. Более того, отечественная наука в постсоветский период не предложила практически ни одного специального исследования монгольского и хорезмийского завоевания Южного Кавказа [39; 37], особенно в сравнении с советским периодом развития отечественного востоковедения $[3 ; 4 ; 17 ; 33 ; 38]$. В связи с этим важно обратить внимание на зарубежный опыт исследования данной научной проблематики и указать основные тенденции в изучении и осмыслении истории Южного Кавказа в первой половине XIII в. В качестве примера современного зарубежного исследования указанной научной проблематики хотелось бы взять монографию Д. Байарсайхан «Монголы и Армяне (1220-1335)» [40], которая, с нашей точки зрения, наилучшим образом иллюстрирует сложившиеся в зарубежной историографии тенденции и подходы к изучению Южного Кавказа эпохи монгольского и хорезмийского завоевания. Безусловно, заявленная автором этого исследования научная цель несколько шире интересующей нас проблематики, в связи с чем мы главным образом сосредоточим свое внимание на тех разделах монографии, которые посвящены хорезмийскому и монгольскому завоеванию Южного Кавказа.

В первую очередь, в работе Д. Байарсайхан «Монголы и Армяне (1220-1335)» нас будет интересовать раздел, посвященный систематизации и анализу исторических источников, которые были использованы автором при написании указанного исследования. Сам по себе анализ данного раздела монографии поможет не только лучше понять, насколько детально проанализирован корпус источников по проблеме, но и дать ответ на вопрос, какие памятники видятся автору наиболее значимыми для описания истории хорезмийского и монгольского завоевания Южного Кавказа. Забегая вперед, отметим, что само по себе хорезмийское и монгольское завоевание Южного Кавказа нашло свое отражение сразу в трех группах памятников, чьи авторы принадлежали к различным этническим и религиозным общностям. Речь идет об арабоперсидских, грузинских и армяноязычных исторических сочинениях. Это само по себе ставит перед любым исследователем указанной научной проблематики задачу не только сравнить информацию из всех трех групп исторических сочинений, но и понять специфические особенности каждой группы исторических источников, выявить причины этого, чтобы объективно рассматривать сведения, содержащиеся в каждом из памятников. Все это само по себе видится нам непростой задачей и будет крайне любопытно показать, как с этим справилась Д. Байарсайхан.

Прежде всего, необходимо отметить, что преимущественное внимание в данном разделе исследования уделено монгольским и армянским источникам. При этом Д. Байарсайхан старательно обходит дискуссию относительно происхождения автора и первоначального языка описания отдельных исторических сочинений, внесенных ею в раздел «Армянские источники», в частности труда Киракоса Гандзакеци. Дискуссия вокруг проблемы авторства и изначального 
языка написания этого памятника, которая развернулась между армянской и азербайджанской исторической школой, безусловно, требует от автора указать на ее существование. Однако вместо этого Д. Байарсайхан без объяснения занимает позицию одной из конфликтующих научных школ, причисляя памятник к армянским источникам $[19 ; 20 ; 1$, с.310-314; 14, с. 55; 194; 30, с. 31-32; 29, c. 88-97]. В дальнейшем можно наблюдать, как исследователь, слепо доверяя источнику, и не пытаясь анализировать его содержание, конструирует «Великую Армению» или же указывает, что Гандзак (Гянджа) находится в северо-восточной Армении [40, p.14,16]. Остается лишь догадываться, как можно было прийти к подобным описаниям с учетом того, что ни «Великой Армении», ни просто Армении как политического образования на тот момент не существовало [37, с. 7-39]. Удивительна в данном случае и последовательность автора: указывая в тексте на наличие «Великой Армении» или некой северо-восточной Армении, она приводит карты Южного Кавказа в XII - XIII вв., где ни того, ни другого просто не указано, следовательно, подобного рода политических образований в этом регионе нет [40, p. 7]. Зато становится понятно, исходя из указанной карты, что на Южном Кавказе существует Грузинское царство, государство Ширваншахов, полунезависимый Арран, а также часть территорий региона входит в состав государства атабеков Азербайджана. В связи с этим вполне закономерно возникает вопрос: если все указанные выше варианты «Армении» не являются политическим образованием, то, что конкретно имеет тогда в виду автор? Внятного ответа на данный вопрос монография Д. Байарсайхан «Монголы и Армяне (1220-1335)» не содержит.

Возвращаясь к тому разделу исследования, где автор систематизирует и анализирует исторические источники по интересующей его научной проблеме, отметим еще несколько важных моментов. Первый из них - неравномерное, с нашей точки зрения, внимание к разным группам исторических сочинений. Если первые два раздела, посвященные монгольским и армянским источникам, представляют собой подробный анализ происхождения того или иного памятника, особенностей биографии авторов, структуры текста, то последующие разделы вряд ли могут похвастаться таким внимательным отношением к историческим сочинениям. Так, в разделе «Персидские источники» большое внимание автора приковано к трудам Рашид ад-Дина, Джувейни и Джузджани [40, p. 26-28], а сочинениям Хамдаллаха Казвини - всего несколько строчек. Не менее удивительно, что там же автор, разбирая арабские памятники, еще меньше внимания уделяет труду ан-Насави [40, p. 29], что мало поддается какой бы то ни было логике: этот историк подробнейшим образом описывает первое монгольское и хорезмийское вторжение в земли Южного Кавказа, а последнему и вовсе был очевидцем $[31 ; 32 ; 46 ; 47]$. Отсутствие в этом разделе указания на сочинение Ибн ал-Асира, где не менее подробно говорится об указанных выше событиях, ставит перед нами вопрос: а стремилась ли Д. Байарсайхан действительно охватить все возможные источники информации по проблеме или же предполагала использовать лишь некоторые из них? В этой связи уже не вызывает вопросов более чем скромное внимание автора к грузинским историческим сочинениям: указывая на «Картлис Цховреба», автор не только не предлагает детального описания истории формирования и структуры данного памятника, но и указывает, что использовала его лишь в частичном армянском издании 1936 г. [40, p. 30]! Таким образом, автор, по-видимому, не осведомлен ни об исследованиях данного источника [7; 13; 27], ни о публикации наиболее важной для данного научного изыскания части этого источника «Столетняя хроника» или «Хронограф» XIV в. [38; 6; 26].

Необходимо остановиться и на историографическом разделе Д. Байарсайхан «Монголы и Армяне (1220-1335)», который не менее любопытен, чем та часть, которая посвящена историческим источникам и была рассмотрена нами выше. Прежде всего читателя удивит небольшой объем историографического раздела представленного исследования $[40$, p. 2-6], и он вполне может прийти к выводу о том, что научная проблематика, которой посвящена работа Д.Байарсайхан, слабо разработана в современной востоковедной науке. Однако при ближайшем рассмотрении этой части работы напрашиваются совершенно иные выводы. Отметим, что среди представленных автором исследований можно увидеть труды европейских, монгольских, армянских ученых, а из советской историографии Д. Байарсайхан преимущественно использует работы также армянских историков - Л.О. Бабаяна [12], А.Г. Галстяна [9] и т.д. Открытым остается вопрос о том, отчего же не представлена вовсе, как минимум, грузинская и азербайджанская историческая школа, которые со своей стороны предложили научной общественности немало исследований по истории Южного Кавказа и сопредельных регионов в монгольскую эпоху $[4 ; 5 ; 8 ; 7 ; 11 ; 14 ; 16 ; 23 ; 24 ; 25 ; 28]$. При этом нельзя сказать, что историографический раздел монографии Д. Байарсайхан исчерпывающ даже в отношении работ 
армянских историков: в работе не упоминаются несколько исследований по монгольским завоевательным походам и их господству на Южном Кавказе и в сопредельных регионах [3; 17].

Таким образом, данный раздел монографии Д. Байарсайхан «Монголы и Армяне (12201335)» характеризуется не только неполнотой историографической базы, но очевидно выборочным подходом к использованию научных исследований по представленной проблеме. Несомненно, подобное отношение к историографии приводит к тому, что вне поля авторского внимания остается значительный массив научных работ, что в свою очередь не может не сказаться на качестве представленной монографии. При этом не следует забывать и о том, что преимущественное внимание к армянским историческим исследованиям приводит к тому, что в отдельных дискуссионных моментах Д. Байарсайхан излагает лишь точку зрения армянской исторической науки, даже не указывая на то, что могут существовать иные взгляды или суждения. Данное высказывание хотелось бы подкрепить следующим примером из представленной монографии.

В первой главе в разделе, касающемся Киликийской Армении, Д. Байарсайхан оставляет без внимания дискуссию относительно происхождения династии Хетумидов, чье армянское происхождение автором не оспаривается и воспринимается как данность $[40$, p. 34-36, 66]. Однако в современной науке существует и иная точка зрения, согласно которой род Хетумидов был албанским по происхождению и лишь со временем подвергся арменизации. Впервые такую точку зрения высказывает в своей работе Ф. Мамедова, которая подробно разбирает, в том числе, историю формирования и расцвета Киликийской Армении и происхождения Хетумидов [29, c.413-442]. Подобную точку зрения разделяют в своих исследованиях и отдельные российские и зарубежные историки, основываясь на различном историческом материале. В частности, на албанском происхождении Хетумидов настаивает в своей работе отечественный специалист 3.В. Кананчев, который, помимо этого указывает, и на то, что в Киликии использовался албанский алфавит [45, s. 63]. Албанское происхождение рода Хетумидов отмечает в своей работе и известный австрийский специалист В. Зайпт, который в статье «Восточные границы Византии в десятилетие после Манцикерта - Могут ли печати помочь в реконструкции событий?» не только локализует место происхождения Хетумидов, но и этимологизирует название этого рода из албанского языка [48, s. 26]. Таким образом, вполне очевидно, что Д. Байарсайхан либо не знает о данной научной дискуссии, либо предпочитает указывать точку зрения лишь одной стороны.

Подходя непосредственно к анализу описания хорезмийского и монгольского завоевания Южного Кавказа в исследовании Д. Байарсайхан «Монголы и Армяне (1220-1335)», следует сказать несколько слов о том, какое внимание уделил автор более ранним монгольским завоевательным походам под командованием Чингиз-хана. Здесь, прежде всего, необходимо выделить войну с государством хорезмшахов-Ануштегинидов, в ходе которой по приказу Чингизхана монгольские отряды под командованием Джебэ и Субэдэя были брошены сначала на поиски хорезмшаха Ала ад-Дина Мухаммада, а затем дошли и до Южного Кавказа. Можно предположить, что подробный анализ войны монголов и государства хорезмшахов не являлся приоритетной задачей для Д. Байарсайхан, исходя из темы ее исследования, однако и эта небольшая часть вызывает у нас определенные вопросы к автору. Прежде всего отметим описание «Отрарского инцидента», при котором автор ссылается не на арабо-персидские источники, а на классическое исследование В.В. Бартольда [40, p. 42], что приводит к тому же результату, что и в случае с династией Хетумидов, о котором было сказано выше. В итоге, вместо того чтобы продемонстрировать различные взгляды на это событие (в тексте монографии об этом не сказано ни слова), автор предпочитает указывать лишь одну точку зрения. Так, у Д. Байарсайхан наместник Отрара, по невыясненным причинам, вырезает торговый караван, который был послан Чингиз-ханом, и тем самым начинает войну между двумя государствами. В то же время в арабоперсидских источниках фигурирует версия о шпионаже и пропаганде со стороны самих участников каравана [31, с. 79], что и стало причиной их ареста и гибели, а также версия о том, что приказ об аресте каравана и его убийстве отдал сам Ала ад-Дин Мухаммад, желая завладеть имуществом купцов $[10$, с. 348$]$. Еще одним важным моментом здесь следует признать указание Д. Байарсайхан на действия монгольского корпуса под командованием Джебэ и Субэдэя: «Монгольские военачальники Субэдэй и Джебэ, преследуя Хорезмшаха в западном направлении, привели монголов в Армению в 1220-м году» [40, р. 42]. Здесь опять же остается лишь догадываться о том, что имеется в виду под понятием «Армения», если такого государства в то время в землях Южного Кавказа и сопредельных регионов просто не существовало. По-видимому, 
ответ на этот вопрос должна дать следующая глава монографии - «Монгольские нойоны в Великой Армении (1220-1245)» [40, p. 43].

Во введении к этой главе Д. Байарсайхан предлагает некоторую картину того, что же она называет «Арменией» в указанный исторический период. «Политическое положение Армении накануне монгольского завоевания олицетворялось различными властями в различных регионах. Так, Селдьжуки (Сальджуки) Рума пришли к власти в западной части с конца двенадцатого века; грузинская династия Багратидов управляла северной и восточной частями с 1089; кроме того, политическое господство Аййубидов начало распространяться в некоторых южных частях с 1208. Только немногие южные территории продолжали оставаться под контролем армянских ишханов (князей). Из них Торникиды/Мамиконяны правили в Сасуне, Аструниды в областях Мокка и Рштуник в Васпуракане» [40, р. 43]. Прежде всего, из данной цитаты следует сделать один важнейший вывод: сама Д. Байарсайхан утверждает, что политического образования «Армения»к эпохе монгольских завоевательных походов не существовало. Однако следом за этим выводом следует вопрос - а зачем же тогда использовать термин, который в данный исторический период не является политонимом? Автор подчеркивает, что большинство территорий «Армении» входили в состав других государственных образований, тогда не проще ли указывать их как земли, населенные армянами или с преимущественно армянским населением в составе Грузинского царства, государства Сельджукидов Рума и так далее? Позволим себе еще раз привести цитату из монографии Д. Байарсайхан: «Монгольские военачальники Субэдэй и Джебэ, преследуя Хорезмшаха в западном направлении, привели монголов в Армению в 1220-м году» [40, p. 42]. Разве не логичнее было бы написать, что монгольские войска вторглись в пределы государства атабеков Азербайджана, Грузинского царства, нежели использовать термин, не имеющий политической основы, в чем признается и сам автор? По всей видимости, перед нами попытка таким образом встроить Армению в средневековую историю, в том числе Южного Кавказа, в обход существовавших тогда политических образований, что может ввести в заблуждение, прежде всего, неспециалиста в данном вопросе.

Еще одним важным моментом следует признать тот факт, что Д. Байарсайхан указывает на независимых армянских правителей в Сасуне, в областях Мокка и в Васпуракане, не указывая при этом, что первые две области не имеют никакого отношения к Южному Кавказу, а относительно Васпуракана мы вновь видим тот же самый авторский прием, о котором говорилось выше игнорирование тех или иных дискуссионных моментов в исторической науке в рамках собственного исследования. Относительно области «Васпарукан», ее границ и населения существует несколько точек зрения: первая из них, основываясь на «Армянской географии VII века» Анания Ширакаци, включает в состав этой области и земли Южного Кавказа [22; 2]. Согласно другой точке зрения, «Васпарукан» включал в себя земли Южного Кавказа лишь крайне небольшой временной промежуток, с 591 г. до VII в., а также являлся территориальногеографической единицей, а не политонимом [29, с. 265-272]. Умалчивая об этой дискуссии, Д. Байарсайхан так и не дает ответа на вопрос о том, почему она использует термины, которые не отражают политических реалий Южного Кавказа и сопредельных регионов начала XIII века.

Описывая первое вторжение монгольских войск в пределы Южного Кавказа, Д. Байарсайхан прежде всего апеллирует к монографии Р. Бедросяна [41, р. 64], видя в монголах лишь этап «тюрко-монгольской экспансии» в пределы «Великой Армении» [40, p. 44]. Иная точка зрения на данное историческое событие [15], как, впрочем, и большинство исследований по данной проблеме $[3 ; 4 ; 5 ; 7 ; 8 ; 11 ; 14 ; 16 ; 17 ; 23 ; 24 ; 25 ; 28]$, в этом разделе монографии Д. Байарсайхан не представлены. О подобной особенности анализируемого исследования мы уже не раз говорили, однако мимо одного пассажа в начале данной работы, как исследователь истории хорезмийского завоевания Южного Кавказа, я просто не могу пройти. Д. Байарсайхан, описывая ряд завоевательных походов тюркских народов в пределы Южного Кавказа, указывает на «завоевание Армении хорезмийцами» [40, р. 44]. Ни отечественная, ни зарубежная историография жизни и деятельности хорезмшаха Джалал ад-Дина Манкбурны, кроме отдельных публикаций, не упоминает о подобном [17]. При этом в указанной работе А.Г. Галстяна есть еще более любопытные нюансы: так, в его работе Армения «обретает» столицу, город Двин, который в этот период входил в состав Грузинского царства [17, с. 168]. Остальные исследователи в своих трудах подчеркивают, что Джалал ад-Дин Манкбурны завоевал государство атабеков Азербайджана, Грузинское царство, Арран, который в тот момент был полунезависимым, и подчинил себе Ширван $[15 ; 36 ; 38 ; 42 ; 44]$. Возможно, следовало бы так и написать, а не указывать государство, которого на тот момент не было. Если же в данном случае речь идет не о политическом 
образовании, а всего лишь о некоторой территории с армянским населением или армянским большинством, то такая позиция Д. Байарсайхан, с нашей точки зрения, также требует пояснения.

Так или иначе, Д. Байарсайхан, с нашей точки зрения, сознательно вводит читателей в заблуждение, хотя ей должно быть известно, что ан-Насави, сопровождавший хорезмшаха Джалал ад-Дина Манкбурны в походах, в том числе и в земли Южного Кавказа, не упоминает ни армянские войска, ни территории с армянским населением, подчиненные этим правителем [31; 32; 46; 47]. Среди более поздних арабо-персидских источников только в тексте Джувейни можно найти упоминание об армянских военных соединениях, которые он упоминает при описании сражения грузинских войск с Джалал ад-Дином в 1228 г.: «было собрано войско, в которое вошли грузины, аланы, армяне, сариры, лакцы, кифчаки, сваны, абхазы, чанеты, сирийцы и румийцы, к которым присоединились мужи, закаленные в огне жизни и избранные в день битвы» [21, с. 310]. Следует отметить, что данная цитата, тем не менее, вызывает вопросы уже потому, что в собственно грузинских источниках нет никаких упоминаний о призвании «сирийцев и румийцев», однако данный перевод труда Джувейни легко проверить по персидскому изданию, и там они также будут упоминаться [43, s.102]. При этом, забегая вперед, хотелось бы отметить, что несоответствие информации из труда Джувейни со сведениями из других арабо-персидских и грузинских источников позволяет скептически рассматривать это сообщение персидского историка, но считать его полностью недостоверным нельзя. Авторы грузинских исторических сочинений, а точнее «Столетняя хроника» или «Хронограф» XIV в., которым прекрасно было известно о составе грузинской армии, таких данных не приводят при том, что в отдельных случаях состав грузинской армии, выступавшей против Джалал ад-Дина Манкбурны, описан ими очень подробно. Здесь мы приведем пример, касающийся того сражения 1228 г., о котором выше пишет Джувейни. «Узнав о том, султан решил, что его и адарбадаганским войскам не выстоять против (татар), покинул Адарбадаган и вновь удалился в Тбилиси. Проведав об этом, царица Русудан созвала все свое воинство, имеров и амеров, мандатуртухуцеса Шаншэ, амирспасалара Авага, мсахуртухуцеса Варама, эров, кахов, сомхитаров, месхов, таойцев, Цотне Дадиани, человека почтенного и благонравного, абхазов, джиков и всех из имерского царства, говорить о коих порознь недосуг. И отверзла Врата Дариальские и впустила овсов, дурдзуков и заодно с ними всех горцев. Собрались в Начармагеви во множестве несчетном, и отправила царица их на войну с хорезмийцами» [26, с. 344].

Таким образом, вместо того чтобы обозначить указанное разночтение в корпусе источников и подчеркнуть дискуссионность информации, приводимой в армяноязычных памятниках, Д.Байарсайхан продолжает приводить сведения из них абсолютно без всякого критического к ним отношения. Важно отметить и то, что при описании монгольского и хорезмийского завоевания Южного Кавказа, автор рассматриваемой монографии, в отличие от часто приводимого понятия «Армения», ни разу не указывает на существование государства атабеков Азербайджана, лишь указывая однажды на неких «правителей Азербайджана и Хлата (Ахлата)» [40, p. 49]. Это также выглядит как сознательное исключение этого государства из описания исторического развития Южного Кавказа в указанный период, хотя оно напрямую связано с событиями и монгольского вторжения, и завоеваний Джалал ад-Дина Манкбурны [14; 18]. Еще менее последователен автор при описании второй волны монгольской экспансии, указывая, что после «разрушения Гадзака монгольская армия разделила по жребию земли Армении, Грузии и Албании» [40, p. 54]. Понятие «Албании» не только не определено автором, но и не встречается при более ранних описаниях монгольских и хорезмийских завоеваний. Вопрос, почему именно в этом случае автор указывает на Кавказскую Албанию, никак не определяя ее границы, а до этого не упоминала вовсе, так и остается без ответа в монографии Д. Байарсайхан.

Наконец, отметим, что судьба хорезмшаха Джалал ад-Дина Манкбурны также описана автором самым причудливым образом: после взятия Хилата этот правитель узнает о приближении войск Чормагана, а потом, в 1231 г., по непонятным (из текста монографии) причинам был убит «местными бандитами» в окрестностях Амида [40, p. 53]. После этого Д. Байарсайхан пишет: «...самый могущественный оппонент Монголов в этом регионе был ликвидирован» [40, p. 53]. Вряд ли можно считать могущественным правителя, чьи основные военные силы были почти полностью уничтожены в 1230 -м году в битве при Йассе-Чамана $[21$, с. $319 ; 10$, с. $397 ; 31$, с. 255; 19, с. $149 ; 34$, с. 24], однако, не указывая на данный факт, остаются непонятными причины, по которым Джалал ад-Дин Манкбурны попал в руки разбойников в окрестностях Амида и был ими убит. Если бы Д. Байарсайхан упомянула о том, что власть хорезмшаха после 1230 -го г. заметно 
ослабла, а его войско значительно уменьшилось, то и дальнейшее описание судьбы Джалал адДина не вызывало бы у читателей никаких вопросов.

Подводя итоги краткого анализа монографии Д. Байарсайхан «Монголы и Армяне (12201335)», хотелось бы отметить несколько самых существенных моментов. Автор в этой работе систематизирует и анализирует корпус исторических источников далеко не в полном объеме, ссылки на отдельные памятники встречаются лишь в самом тексте, как например, сочинение Ибн ал-Асира [40, p. 45], а о других памятниках приводится крайне скудная информация, особенно в сравнении с авторским описанием армяноязычных источников. Эти последние, если следовать тексту работы и являются основными для автора источниками информации, наряду с монгольской и китайской историографией. При этом, как и во всем тексте исследования, Д. Байарсайхан сознательно исключает из поля зрения большинство дискуссионных моментов, в том числе связанных с происхождением того или иного памятника. Любые разногласия между источниками относительно тех или иных сюжетов старательно замалчиваются. При описании монгольского и хорезмийского завоевания Южного Кавказа Д. Байарсайхан следует информации преимущественно из армяноязычных памятников, что, как показало данное исследование, приводит к курьезам и ошибкам. Авторский подход к историографии также не выдерживает никакой критики: исследования представлены не в полном объеме, кроме того - полностью исключены отдельные советские востоковедческие труды, а также азербайджанская, грузинская и турецкая историография проблемы.

Не менее важна и еще одна деталь, а именно Д. Байарсайхан на протяжении всего исследования сознательно использует понятие «Армения» или «Великая Армения», не давая объяснений о том, что перед нами - политоним или что-то иное. Несмотря на противоречия в собственном же исследовании, несоответствие сведений в тексте с приводимой картой, автор настойчиво подчеркивает существование «Армении», при этом признавая, что по сути такого государства не существовало в указанный период. На фоне этого крайне любопытным выглядит единичное упоминание при описании монгольских и хорезмийских походов Кавказской Албании и полное отсутствие указаний на государство атабеков Азербайджана. С нашей точки зрения, данный момент следует расценивать, как попытку вписать Армению как политическое образование в тот исторический контекст, когда этого государства просто существовать не могло. Вполне вероятно, осознанно или нет, Д. Байарсайхан политизирует историю Южного Кавказа, защищая в своей работе идею «постоянного политического присутствия» Армении в регионе. Такого рода особенность работы Д. Байарсайхан не только вызывает вопросы относительно объективности и непредвзятости данного исследователя, но и прекрасно коррелируется с определенными тенденциями в историографии Южного Кавказа не только за рубежом, но и в России [35].

Описание монгольского и хорезмийского завоевания Южного Кавказа в монографии Д. Байарсайхан выглядит достаточно сжатым, особенно в отношении военных действий хорезмшаха Джалал ад-Дина Манкбурны. Помимо отдельных ошибок и недочетов в этой части исследования, мы также видим указанные выше общие особенности представленной монографии: слепое доверие к источнику, отсутствие упоминаний о любых дискуссионных сюжетах и выборочный подход к историографии проблемы. В результате можно встретить указание Д. Байарсайхан на участие армянских военных соединений в борьбе с монгольскими завоевателями в составе грузинской армии, о чем нет упоминаний ни в грузинских источниках, ни в большинстве арабоперсидских памятников. В целом, для исследователя монгольского и хорезмийского завоевания Южного Кавказа, определенная часть работы Д. Байарсайхан, описывающая соответствующие исторические события, не предлагает ни кардинально новых сведений или авторских выводов, ни новых интерпретаций исторических источников. В связи с этим совершенно не удивителен тот факт, что Д. Байарсайхан указывает, что с текстом ее работы ознакомились виднейшие специалисты по истории монгольской экспансии и империи Чингиз-хана и его потомков, но при этом в этом списке не нашлось места ни одному специалисту по истории собственно Южного Кавказа [40, р. 1]. У читателя-неспециалиста данная монография способна сформировать представление о том, что в истории Южного Кавказа эпохи монгольского нашествия не только не осталось «белых пятен», но и отсутствуют любые серьезные историографические, источниковедческие и исторические дискуссии. Со своей стороны, мы постарались развеять это возможное заблуждение в рамках небольшого анализа работы Д. Байарсайхан.

\section{ЛИТЕРАТУРА}


1. Абегян М. История древнеармянской литературы. Ереван, 1948. Т.1. - 524 с.

2. Абрамян А.Г., Петросян Г.Б. Анания Ширакаци. Ереван, 1970. - 176 с.

3. Аветисян B. Монгольское нашествие на Армению (XIII в.) // Московский институт востоковедения. Труды. Сб. № 1. М., 1939. С. 125-143.

4. Али-Заде A.A. Монгольские завоеватели в Азербайджане и сопредельных странах в XIIIXIV вв. // Вопросы истории. 1952. № 8. С. 59-65.

5. Али-Заде А.К. Социально-экономическая и политическая история Азербайджана XIIIXIV вв. Баку, 1956. -420 с.

6. Анонимный грузинский «Хронограф» XIV века / Пер.: Г. В. Цулая. М., 2005. - 152 с.

7. Анчабадзе Г.З. Источниковедческие проблемы военной истории Грузии. (Исследование грузинских исторических сочинений). Тб., 1990. - 256 с.

8. Анчабадзе 3.В. Из истории средневековой Абхазии (XI-XVII вв.). Сухуми, 1959. - $306 \mathrm{c}$.

9. Армянские источники о монголах. Извлечение из рукописей XIII-XIV вв. / Пер. А.Г. Галстян. М., 1962. -155 с.

10. ал-Асир ибн. «Ал-Камил фи-т-тарих» «Полный свод по истории». Избранные отрывки / Пер. П.Г. Булгаков, Ш.С. Камолиддин. Т., 2006.

11. Ашурбейли С. Государство Ширваншахов (VI-XVI вв.). Баку, 1983. -306 с.

12. Бабаян Л.О. Социально-экономическая и политическая история Армении в XIII-XIV веках. М., 1969. $-336 \mathrm{c}$.

13. Барамидзе А., Радиани Ш., Жгенти В. История грузинской литературы. М., 1952. - 336 с.

14. Буниятов 3.М. Государство Атабеков Азербайджана (1136-1225). Баку, 1978. - 271 с.

15. Буниятов 3.М. Государство Хорезмшахов-Ануштегинидов 1097-1231 г. М., 1986. - 247 с.

16. Буниятов 3.M. Ширван в XII - первой половине XIII века // Известия АН АзССР, серия ист., философии и права. 1975, №4. С. 29-43; 1976, №2. С. 60-74.

17. Галстян А.Г. Завоевание Армении монгольскими войсками // Татаро-монголы в Азии и Европе. М., 1977. С. 166-186.

18. Гусейнов Р.А. Иракские Сельджукиды, Ильдегизиды и Закавказье // Палестинский сборник. Л., 1970. Вып. 21: Ближний Восток и Иран. С. 185-198.

19. Гандзакеци Киракос. История Армении / Пер.: Л.А. Ханларян. М., 1976. - 355 с.

20. Гандзакеии Киракос. История / Пер. с древнеарм. Т.И. Тер-Григоряна. Баку, 1946. 302 с.

21. Джувейни. Чингиз-хан. История завоевателя мира / Пер.: Е.Е. Харитонова.М., 2004.-690с.

22. Еремян C.T. Армения по «Ашхарацуйц»-у (Армянской географии VII века) (опыт реконструкции армянской карты VII века на современной картографической основе). Ереван, 1963. - $152 \mathrm{c}$.

23. Ибрагимов Д. К истории государства Ширваншахов Азербайджана (1072-1382) // Азербайджанский государственный университет. История и философия. 1964. Вып. 4. С. 17-30.

24. История Азербайджана / Ред. И. А. Гусейнов. Баку, 1958. Т. 1. - 423 с.

25. История Грузии. С древнейших времен до 60-х гг. XIX в. / Сост. Н А. Бердзенишвили, В. Д. Дондуа, М. К. Думбадзе, Г. А Меликишвили, Ш А. Месхиа. Тб., 1962. Т. І. - 510 с.

26. Картлис Цховреба (История Грузии) / Гл. ред. Роин Метревели. Тб., 2008. - 456 с.

27. Кикнадзе Р.К. Очерки по источниковедению истории Грузии: Парсадан Горжджанидзе и «Картлис Цховреба». Тб., 1990. - 201 с.

28. Лордкипанидзе М.Д. История Грузии ХІ - начала ХІІІ в. Тб., 1974. - 210 с.

29. Мамедова Ф. Кавказская Албания и албаны. Баку, 2005. - 798 с.

30. Мамедова Ф. Политическая история и историческая география Кавказской Албании (ІІв. до н.э.-VIII в.н.э.). Баку, 1986. -280 с.

31. Ан-Насави Шихаб ад-Дин Мухаммад. Жизнеописание султана Джалал ад-Дина Манкбурны / Пер. 3.М. Буниятова. Баку, 1973.

32. ан-Насави Шихаб ад-Дин Мухаммад. Сират ас-султан Джалал ад-Дин Манкбурны/ Критич. текст, пер. с араб., предисл., коммент., примеч. и указ. 3.М. Буниятова. М., 1996. 804 с.

33. Петрушевский И.П. Из героической борьбы Азербайджанского народа в XIII-XIV веках. Баку, 1941. - 64 c.

34. Себастаии. «Летопись» // Армянские источники о монголах. Извлечение из рукописей XIII-XIV вв. / Пер. А.Г. Галстян. М., 1962. С. 23-34. 
35. Тимохин Д.М. О некоторых особенностях развития отечественной историографии истории Южного Кавказа в первой половине XIII века // Transcaucasica. Южный Кавказ и сопредельные регионы: источники и историография. М., 2014. С. 75-91.

36. Тимохин Д.М. Соперник Чингиз-хана: хорезмшах Джалал ад-Дин Манкбурны, личность и эпоха. М., 2013. - 268 c.

37. Тимохин Д.М. Хорезмийское государство Джалал ад-Дина Манкбурны и Южный Кавказ 1225-1231 гг. // Транскавказика. Южный Кавказ и сопредельные регионы в эпоху монгольского владычества XIII-XIV вв. М., 2013. С. 7-39.

38. Цулая Г.В. Джелал ад-Дин в оценке грузинской летописной традиции // Летописи и хроники. 1980 г. М.: Наука, 1981. С. 112-128.

39. Шагинян А.К. Армения, Азербайджан и Южный Кавказ в древности и средние века: Учебник. СПб., 2012. - 214 с. $-268 \mathrm{p}$.

40. Bayarsaikhan Dashdondog. The Mongols and the Armenians (1220-1335). Leiden, Brill, 2011.

41. Bedrosian R. The Turco-Mongol Invasions and the Lords of Armenia in the 13-14th Centuries: Ph.D. Dissertation. Columbia University, 1979. - 223 p.

42. Dabir Seyagi. Sultan Djalal ad-Din Horezmshah. Tehran, 1977. -210 p.

43. Djuveini. Jelde dovom az tarihi Jahangoshai Juvaini. Tehran, 1958. $-120 \mathrm{~s}$.

44. Kafesoglu I. Harezmsahlar devleti tarihi (485-617/1092-1229). Ankara, 1956. 420 p.

45. Kananchev Z.V. Die albanische Schrift - zum Problem „Mesrop Maštoc"“// The Creation of the Caucasian alphabets as phenomen Cultural history. Referate des Internationalen Symposions (Wien, 1-4 Dezember 2005). Wien, 2011. S. 55-64.

46. An-Nasavi Nur ad-Din Muhammad Zeydary. Sirat-e Jelal-e ad-Din ya Tarih-e Jelali / Trans. Mohammad Ali Naseh. Tehran, 1945. - 360 s.

47. ün-Nesevî Ahmed Şehabeddin. Celâlüttin Harezemşah / Mütercimi: Necip Âsım [Yazıksız]. İstanbul, 1934. - $158 \mathrm{p}$.

48. Seibt $W$. The eastern frontier of Byzantium in decennia after Manzikert - Can seals help reconstruct developments? // Studies in Byzantine Sigillography / Edited by J.-Cl. Cheynet, Cl. Sode. Vol.12. Berlin-Boston, 2016. S. 25-32.

\section{REFERENCES}

1. Abegjan M. Istorija drevnearmjanskoj literatury. Erevan, 1948. t.1. $-524 \mathrm{~s}$.

2. Abramjan A.G., Petrosjan G.B. Ananija Shirakaci. Erevan, 1970. - 176 s.

3. Avetisjan $V$. Mongol'skoe nashestvie na Armeniju (XIII v.) // Moskovskij institut vostokovedenija. Trudy. Sb. № 1. M., 1939. S. 125-143.

4. Ali-Zade A.A. Mongol'skie zavoevateli v Azerbajdzhane i sopredel'nyh stranah v XIII-XIV vv. // Voprosy istorii. 1952. № 8. S. 59-65.

5. Ali-Zade A.K. Social'no-jekonomicheskaja i politicheskaja istorija Azerbajdzhana XIII-XIV vv. Baku, 1956. $-420 \mathrm{~s}$.

6. Anonimnyj gruzinskij «Hronograf» XIV veka / Per.: G.V. Culaja. M., 2005. - $152 \mathrm{~s}$.

7. Anchabadze G.Z. Istochnikovedcheskie problemy voennoj istorii Gruzii. (Issledovanie gruzinskih istoricheskih sochinenij). Tb., 1990. - $256 \mathrm{~s}$.

8. Anchabadze Z.V. Iz istorii srednevekovoj Abhazii (XI-XVII vv.). Suhumi, 1959. -306 s.

9. Armjanskie istochniki o mongolah. Izvlechenie iz rukopisej XIII-XIV vv. / Per. A.G. Galstjan. M., 1962. $-155 \mathrm{~s}$.

10. al-Asir ibn. «Al-Kamil fi-t-tarih» «Polnyj svod po istorii». Izbrannye otryvki / Per. P. G. Bulgakov, Sh. S. Kamoliddin. T., 2006.

11. Ashurbejli S. Gosudarstvo Shirvanshahov (VI-XVI vv.). Baku, 1983. $306 \mathrm{~s}$.

12. Babajan L.O. Social'no-jekonomicheskaja i politicheskaja istorija Armenii v XIII-XIV vekah. M., 1969. - $336 \mathrm{~s}$.

13. Baramidze A., Radiani Sh., Zhgenti V. Istorija gruzinskoj literatury. M., 1952. - s.

14. Bunijatov Z.M. Gosudarstvo Atabekov Azerbajdzhana (1136-1225). Baku, 1978. - $271 \mathrm{s.}$

15. Bunijatov Z.M. Gosudarstvo Horezmshahov-Anushteginidov 1097-1231 g. M., 1986. 247 s.

16. Bunijatov Z.M. Shirvan v XII - pervoj polovine XIII veka // Izvestija AN AzSSR, serija ist., filosofii i prava. 1975. №4. S. 29-43; 1976, №2. S. 60-74. 
17. Galstjan A.G. Zavoevanie Armenii mongol'skimi vojskami // Tataro-mongoly v Azii i Evrope. M., 1977. S. 166-186.

18. Gusejnov R.A. Irakskie Sel'dzhukidy, Il'degizidy i Zakavkaz'e // Palestinskij sbornik. L., 1970. Vyp. 21: Blizhnij Vostok i Iran. S. 185-198.

19. Gandzakeci Kirakos. Istorija Armenii / Per.: L. A. Hanlarjan. M., 1976. - 355 s.

20. Gandzakeci Kirakos. Istorija / Per. s drevnearm. T. I. Ter-Grigorjana. Baku, 1946. - 302 s.

21. Dzhuvejni. Chingiz-han. Istorija zavoevatelja mira / Per.: E.E. Haritonova. M., 2004. -690 s.

22. Eremjan S.T. Armenija po «Ashharacujc»-u (Armjanskoj geografii VII veka) (opyt rekonstrukcii armjanskoj karty VII veka na sovremennoj kartograficheskoj osnove). Erevan, 1963. $152 \mathrm{~s}$.

23. Ibragimov D.K istorii gosudarstva Shirvanshahov Azerbajdzhana (1072-1382) // Azerbajdzhanskij gosudarstvennyj universitet. Istorija i filosofija. 1964. Vyp. 4. S. 17-30.

24. Istorija Azerbajdzhana / Red. I. A. Gusejnov. Baku, 1958. T. 1. - 423 s.

25. Istorija Gruzii. S drevnejshih vremen do 60 -h gg. XIX v. / Sost. N A. Berdzenishvili, V. D.

Dondua, M.K. Dumbadze, G. A Melikishvili, Sh A. Meshia. Tb., 1962. T. I. - 510 s.

26. Kartlis Chovreba (Istorija Gruzii) / Gl. red. Roin Metreveli. Tb., 2008. - 456 s.

27. Kiknadze R.K. Ocherki po istochnikovedeniju istorii Gruzii: Parsadan Gorzhdzhanidze i «Kartlis Chovreba». Tb., 1990. -201 s.

28. Lordkipanidze M.D. Istorija Gruzii XI - nachala XIII v. Tb., 1974. - 210 s.

29. Mamedova F. Kavkazskaja Albanija i albany. Baku, 2005. - 798 s.

30. Mamedova F. Politicheskaja istorija i istoricheskaja geografija Kavkazskoj Albanii (III v. do n.je.-VIII v.n.je.). Baku, 1986. -280 s.

31. An-Nasavi Shihab ad-Din Muhammad. Zhizneopisanie sultana Dzhalal ad-Dina Mankburny / Per. Z. M. Bunijatova. Baku, 1973.

32. An-Nasavi Shihab ad-Din Muhammad. Sirat as-sultan Dzhalal ad-Din Mankburny / Kritich. tekst, per. s arab., predisl., komment., primech. i ukaz. Z.M. Bunijatova. M., 1996. - 804 s.

33. Petrushevskij I.P. Iz geroicheskoj bor'by Azerbajdzhanskogo naroda v XIII-XIV vekah. Baku, 1941. $-64 \mathrm{~s}$.

34. Sebastaci. «Letopis'»// Armjanskie istochniki o mongolah. Izvlechenie iz rukopisej XIII-XIV vv. / Per. A.G. Galstjan. M., 1962. S. 23-34.

35. Timohin D.M. O nekotoryh osobennostjah razvitija otechestvennoj istoriografii istorii Juzhnogo Kavkaza v pervoj polovine XIII veka // Transcaucasica. Juzhnyj Kavkaz i sopredel'nye regiony: istochniki i istoriografija. M., 2014. S. 75-91.

36. Timohin D.M. Sopernik Chingiz-hana: horezmshah Dzhalal ad-Din Mankburny, lichnost' i jepoha. M., 2013. $-268 \mathrm{~s}$.

37. Timohin D.M. Horezmijskoe gosudarstvo Dzhalal ad-Dina Mankburny i Juzhnyj Kavkaz 12251231 gg. // Transkavkazika. Juzhnyj Kavkaz i sopredel'nye regiony v jepohu mongol'skogo vladychestva XIII-XIV vv. M., 2013. S. 7-39.

38. Culaja G.V. Dzhelal ad-Din v ocenke gruzinskoj letopisnoj tradicii // Letopisi i hroniki. $1980 \mathrm{~g}$. M.: Nauka, 1981. S. 112-128.

39. Shaginjan A.K. Armenija, Azerbajdzhan i Juzhnyj Kavkaz v drevnosti i srednie veka: Uchebnik. $\mathrm{SPb} ., 2012 .-214 \mathrm{~s}$.

40. Bayarsaikhan Dashdondog. The Mongols and the Armenians (1220-1335). Leiden, Brill, 2011. $-268 \mathrm{p}$.

41. Bedrosian R. The Turco-Mongol Invasions and the Lords of Armenia in the 13-14th Centuries: Ph.D. Dissertation. Columbia University, 1979. - 223 p.

42. Dabir Seyagi. Sultan Djalal ad-Din Horezmshah. Tehran, 1977. -210 p.

43. Djuveini. Jelde dovom az tarihi Jahangoshai Juvaini. Tehran, 1958. - $120 \mathrm{~s}$.

44. Kafesoglu I. Harezmsahlar devleti tarihi (485-617/1092-1229). Ankara, 1956. - 420 p.

45. Kananchev Z.V. Die albanische Schrift - zum Problem „Mesrop Maštoc“"// The Creation of the Caucasian alphabets as phenomen Cultural history. Referate des Internationalen Symposions (Wien, 1-4 Dezember 2005). Wien, 2011. S. 55-64.

46. An-Nasavi Nur ad-Din Muhammad Zeydary. Sirat-e Jelal-e ad-Din ya Tarih-e Jelali / Trans. Mohammad Ali Naseh. Tehran, 1945. - 360 s.

47. ün-Nesevî Ahmed Şehabeddin. Celâlüttin Harezemşah / Mütercimi: Necip Âsım [Yazıksız]. İstanbul, 1934. $-158 \mathrm{p}$. 
48. Seibt W. The eastern frontier of Byzantium in decennia after Manzikert - Can seals help reconstruct developments? // Studies in Byzantine Sigillography / Edited by J.-Cl. Cheynet, Cl. Sode. Vol.12. Berlin-Boston, 2016. S. 25-32. 